\title{
Taxonomic value of histochemical features of the style in early lineages of Asteraceae
}

\author{
Marcelo Paulo Hernández ${ }^{1}$, Liliana Katinas ${ }^{1,2}$ and Ana María Arambarri1 ${ }^{*}$
}

Received: July 5, 2015 Accepted: September 10, 2015

\begin{abstract}
In this paper we examine lipophilic substances, tannins, proteins, reducing carbohydrates, starch, and oxalate salts in early lineages of Asteraceae to test if they are a useful complement to classification studies. Styles of mature flowers of 44 species were processed according to plant histochemical techniques and observed by means of a light microscope. Lipophilic compounds were always present in the cuticle and cell walls, and in some species were located inside the cells. Proteins were located in the style cell walls and cell interior of most of the analyzed species. No tannins were found. In general, there is a correlation in the presence of reducing sugars and proteins. Starch granules and oxalate salts were found in the style parenchyma of a few species. Cytoplasmic content of lipophilic compounds, proteins, and reducing sugars predominates in Barnadesioideae and Nassauvieae (Mutisioideae), and histochemical similarities were found among members of Gochnatioideae.
\end{abstract}

Keywords: Compositae, crystal salts, lipophilic substances, proteins, starch, sugars, taxonomy

\section{Introduction}

Asteraceae is one of the largest families of angiosperms with wide distribution and diverse habitats (Funk et al. 2009). The bifid style of Asteraceae has been traditionally established as one of the diagnostic features for the family and modifications of this basic pattern have been used to distinguish infrafamilial taxonomic categories such as subfamilies, tribes, and subtribes (e.g. Bentham \& Hooker 1873; Cabrera 1961; Bremer 1994). Typically, the style in Asteraceae is apically divided into two short or long branches with the stigmatic area on the inner (adaxial) surface, whereas the outer (abaxial) surface may be smooth or covered by papillae called "sweeping hairs" that brush the pollen through the tube that form the introrse, connate anthers (Bremer 1994). The styles of early lineages of the phylogenetic tree of Asteraceae, i.e., subfamilies Barnadesioideae (nine genera, ca. 90 species) and Mutisioideae sensu lato (s.l.; 74 genera, ca. 865 species) were broadly analyzed by Crisci (1974), Cabrera (1977), and Katinas et al. (2008a). A subfamily Mutisioideae sensu stricto (45 genera, ca. 730 spp.) is also recognized (e.g., Funk et al. 2009) on the basis of phylogenies obtained with molecular data, comprising many clades, some of them established as tribes and subfamilies. Mutisioideae s.l., which comprises the tribes Mutisieae, Nassauvieae, and Stifftieae, is morphologically circumscribed by pollen features and a "mutisioid" style, i.e., with the outer face of the branches smooth, rugulose, or with short and rounded sweeping hairs (Katinas et al. 2008a). Within the mutisioid style, three groups may be recognized: the style branches are smooth or papillose (tribe Mutisieae); the style branches are apically crowned by a tuft of sweeping hairs (tribe Nassauvieae); or the style branches are rugulose or with the sweeping hairs covering the branches and also extending below the branch bifurcation point (tribe Stifftieae) (Katinas et al. 2008a). The first and third types are shared with members of Barnadesioideae. Thus, the style morphology provided interesting features by which members of the basal lineages of Asteraceae may be distinguished and compared. We wonder if these morphological differences are also reflected in histochemistry variations.

Histochemistry is so far relatively unknown in Asteraceae and could be promising in yielding new characters that can help differentiating basal members from more derived groups of the phylogenetic tree of Asteraceae. Most studies developed in Asteraceae refer to either the recognition of secondary metabolites (e.g., Bohm \& Stuessy 2001), the chemistry of the stigmatic surface in relation to the pollen-stigma interaction and the transmitting tissue of styles (e.g., Knox 1973; Hiscock 2000; Bessa et al. 2010; Gotelli et al. 2010), or the qualitative identification of organic

\footnotetext{
${ }^{1}$ Laboratorio de Morfología Comparada de Espermatófitas, Facultad de Ciencias Agrarias y Forestales, UNLP. 60 y 119, C.C. 31 , 1900, La Plata, Argentina ${ }^{2}$ División Plantas Vasculares, Museo de la Plata (Facultad de Ciencias Naturales y Museo), Paseo del Bosque s/n, C.C. 31, 1900, La Plata, Argentina

* Corresponding author: anaramba@yahoo.com.ar.
} 
compounds (proteins, carbohydrates, lipids) in medicinal plants or floral biology (Schorr \& Costa 2003; Edeoga et al. 2005; Korwar et al. 2010; Nascimento-Silva et al. 2011; Pansarin et al. 2014). In this paper we examine lipophilic substances, tannins, proteins, reducing carbohydrates, starch, and oxalate in the styles of selected members of basal Asteraceae as an innovative approach to test if histochemical microanalysis techniques are a useful tool to complement classification studies.

\section{Materials and Methods}

\section{Materials}

This study is based on the investigation of styles of matures flowers of seven genera and 11 species of Barnadesioideae (nine genera, ca. 92 species), three genera and three species of Gochnatioideae (four genera, ca. 88 species), 19 genera and 25 species of Mutisioideae sensu stricto (44 genera, ca. 630 species), four genera and four species of Stifftioideae (nine genera, ca. 37 species), and one genus and one species of Wunderlichioideae (four genera, 36 species) (Funk et al. 2009) (see Supplementary material). The terms style, stigma and sweeping hairs as used in this paper, follow definitions according to Small (1919) and Bremer (1994).

\section{Histochemical Analysis}

Fresh style samples of available species of Asteraceae were used to test histochemical reactions before to perform this study and the results were compared with the reactions performed in herbarium material. No differences were found between both types of samples.

The flowers from herbarium specimens were reconstituted by immersion in water using an oven at $30^{\circ} \mathrm{C}$ for $24-72$ h. To avoid alterations they were fixed with $\mathrm{FAA}_{70}$ (formalin: glacial acetic acid: ethanol 70\%) (Johansen 1940). The fixed material was washed twice with sterilized distilled water. Several flowers of each species were dissected separating the styles. For cytochemical analyses entire styles or longitudinal sections of them were bleached in sodium hypochlorite (50\%) and washed twice with distilled water. After that, reactions were performed and temporary or semipermanent slides were made using as mountage medium glycerine (90\%) and gelatin-glycerin, respectively.

For detection of lipophilic substances the transparent styles were immersed in ethanol (EtOH, 70\%) solution of Sudan IV for 15 min, and differentiated with EtOH (70\%) for about $1 \mathrm{~min}$. A reddish color on cell walls and red drops into the cells indicated the presence of lipophilic components (Ruzin 1999). Detection of tannins was performed on slide with a few drops of neutral ferric chloride solution $(10 \%)$ and a drop of sodium carbonate (2\%). The formation of greenish blue color indicated the presence of tannins (Zarlavsky 2014). For detection of proteins was performed the Biuret test, in which the transparent styles were deposited on the slides, dried with a paper to completely remove water, then a drop of reagent was added. The formation of blue violet color indicated the presence of proteins (Korwar et al. 2010). The same procedure was used to detect reducing sugars by the Benedict's test, but after deposite a drop of reagent, slides was flaming on lighter 3-4 times. The formation of orange red color was positive (Korwar et al. 2010).The starch test was performed on slide with a drop of Iodine-Potassium-Iodide (IKI). Small grains dark blue into the style indicated presence of starch (Ruzin 1999). To distinguish if crystals were oxalate and non carbonate or phosphate salt, the bleached styles were immersed into glacial acetic acid (5\%) for $30 \mathrm{~min}$. The persistence of crystals indicated presence of oxalate salt (Yasue 1969). Results were examined by means of a Leitz SM Lux microscope. Photomicrographs were taken with a Moticam 2300 attached to the eyepiece microscope, and software Motic Image Plus 2.0, and a Nikon Coolpix S10 camera.

\section{Character reconstruction}

The Table 1 was converted into a matrix of five characters: lipophilic substances, proteins, reducing sugars, starch, and druses, with the presence of the compound coded as 1 and the absence coded as 0 . For character reconstruction, we used the most recent molecular-based phylogeny of the family Asteraceae according Funk et al. (2009), pruning those taxa not included in our analysis. Because this tree is resolved only at generic level and our study is based on species, the phylogenies of some particular taxonomic groups were taken from additional studies and included in the base tree: Barnadesioideae from Stuessy et al. (2009), Gochnatioideae from Funk et al. (2014), Mutisieae sensu stricto from Panero \& Funk (2008), and Nassauvieae from Katinas (1994) and Katinas et al. (2008b). Species treated by us but not included in any phylogenetic analyses, were considered as a polytomy when there were more than two species of the same genus (e. g. Dasyphyllum Kunth), or they were considered sister species when there were only two species of the same genus (e.g., species of Fulcaldea Poir.ex Lam., Trixis P. Browne ). The character matrix was optimized on the constructed phylogenetic tree using the option "Show reconstruction" of PAUP 4.0a129 (Swofford 2002).

\section{Results}

The reactions observed in the tissues of styles to the different tests resulted as follows (Tab. 1):

Lipophilic substances (LS): They were present in the cuticle and epidermal cell walls of style of all the analyzed species. In most species, drops of lipophilic substances were found as cell content (LS in Tab. 1) in epidermal and parenchyma tissues of the style (Fig. 1A-B), and it was also found in the sweeping hairs (Fig. 1C-F). The stigmatic cells, on the other 
Table 1. Histochemical results arranged according to the classification of Funk et al. (2009) for metabolites contained into cells: lipophilic substances (LS); proteins $(\mathrm{P})$; reducing sugars (RS); starch (S), and druses (D). The chemical components are indicated: presence (+); absence (-).

\begin{tabular}{|c|c|c|c|c|c|c|}
\hline Subfamily & Species & LS & $\mathrm{P}$ & RS & $\mathrm{S}$ & $\mathrm{D}$ \\
\hline \multicolumn{7}{|l|}{ Tribe } \\
\hline \multicolumn{7}{|c|}{ BARNADESIOIDEAE } \\
\hline \multirow[t]{11}{*}{ Barnadesieae } & Barnadesia odorata & + & + & + & - & - \\
\hline & Chuquiraga erinacea & + & + & + & - & - \\
\hline & Dasyphyllum brasiliense & + & + & + & - & - \\
\hline & Dasyphyllum ferox & + & - & - & - & - \\
\hline & Dasyphyllum spinescens & + & + & + & - & - \\
\hline & Dasyphyllum tomentosum & + & + & - & + & - \\
\hline & Doniophyton anomalum & + & + & + & - & - \\
\hline & Fulcaldea laurifolia & - & + & - & - & - \\
\hline & Fulcaldea stuessyi & + & + & - & + & - \\
\hline & Huarpea andina & + & + & + & - & - \\
\hline & Schlechtendalia luzulaefolia & + & + & + & - & - \\
\hline \multicolumn{7}{|c|}{ GOCHNATIOIDEAE } \\
\hline \multirow[t]{3}{*}{ Gochnatieae } & Cnicothamnus lorentzii & + & + & + & - & - \\
\hline & Cyclolepis genistoides & + & + & + & - & - \\
\hline & Gochnatia glutinosa & + & + & + & - & - \\
\hline \multicolumn{7}{|c|}{ MUTISIOIDEAE sensu stricto } \\
\hline \multirow[t]{9}{*}{ Mutisieae } & Brachyclados caespitosus & + & + & - & - & - \\
\hline & Chaetanthera flabellata & - & - & - & - & - \\
\hline & Chaetanthera glabrata & + & - & - & - & + \\
\hline & Chaptalia integerrima & - & + & - & - & - \\
\hline & Mutisia acerosa & - & - & - & - & - \\
\hline & Mutisia acuminata & - & + & + & + & - \\
\hline & Pachylaena atriplicifolia & - & + & + & - & - \\
\hline & Trichocline aurea & + & + & + & + & + \\
\hline & Trichocline auriculata & + & - & - & + & - \\
\hline \multirow[t]{15}{*}{ Nassauvieae } & Ameghinoa patagonica & - & + & + & - & + \\
\hline & Dolichlasium lagascae & - & - & - & + & - \\
\hline & Holocheilus brasiliensis & + & + & - & - & - \\
\hline & Jungia pauciflora & - & + & - & - & + \\
\hline & Leucheria candidissima & + & + & + & - & - \\
\hline & Leucheria floribunda & + & + & + & - & - \\
\hline & Macrachaenium gracile & + & + & + & - & - \\
\hline & Nassauvia aculeata & + & + & + & - & + \\
\hline & Nassauvia glomerulosa & + & + & + & - & - \\
\hline & Panphalea smithii & + & + & + & + & - \\
\hline & Perezia multiflora & - & + & - & - & - \\
\hline & Polyachyrus carduoides & + & + & + & - & - \\
\hline & Proustia cuneifolia & + & + & + & - & - \\
\hline & Trixis divaricata & + & + & - & - & - \\
\hline & Trixis grisebachii & + & - & - & - & + \\
\hline Onoserideae & Aphyllocladus spartioides & + & - & - & + & - \\
\hline \multicolumn{7}{|c|}{ STIFFTIOIDEAE } \\
\hline & Dinoseris salicifolia & - & - & - & - & - \\
\hline & Hyaloseris cinerea & + & + & + & + & - \\
\hline & Salcedoa mirabaliarum & + & + & + & + & - \\
\hline & Sitfftia chrysantha & - & + & + & - & - \\
\hline \multicolumn{7}{|c|}{ WUNDERLICHIOIDEAE } \\
\hline & Wunderlichia mirabilis & + & + & + & + & - \\
\hline
\end{tabular}


hand, showed no content of lipophilic substances or it was very scarce. It was evidenced by the pale red or whitish reaction (Fig. 1D-F). Within Barnadesioideae, all the analyzed species have drops of lipophilic substances in the cell interior being the only exception Fulcaldea laurifolia (Tab. 1).

Tannins: The presence of this compound resulted negative in the styles of all the species analyzed.

Proteins (P): The presence of proteins was located in the style cell walls and in the cell interior of most of the analyzed species (Fig. 2A-B), with the exception of one species of Barnadesioideae (Dasyphyllum ferox), four of the nine species analyzed of the tribe Mutisieae (Mutisioideae), two species of Nassauvieae (Dolichlasium lagascae, Trixis grisebachii; Mutisioideae), one species of Onoserideae (Mutisioideae), and one of the four Stifftioideae (Tab. 1).

Reducing sugars (RS): These compounds were found in the style parenchyma (Fig. 2C) of most species. Within Barnadesioideae, the most analyzed species have reducing sugars
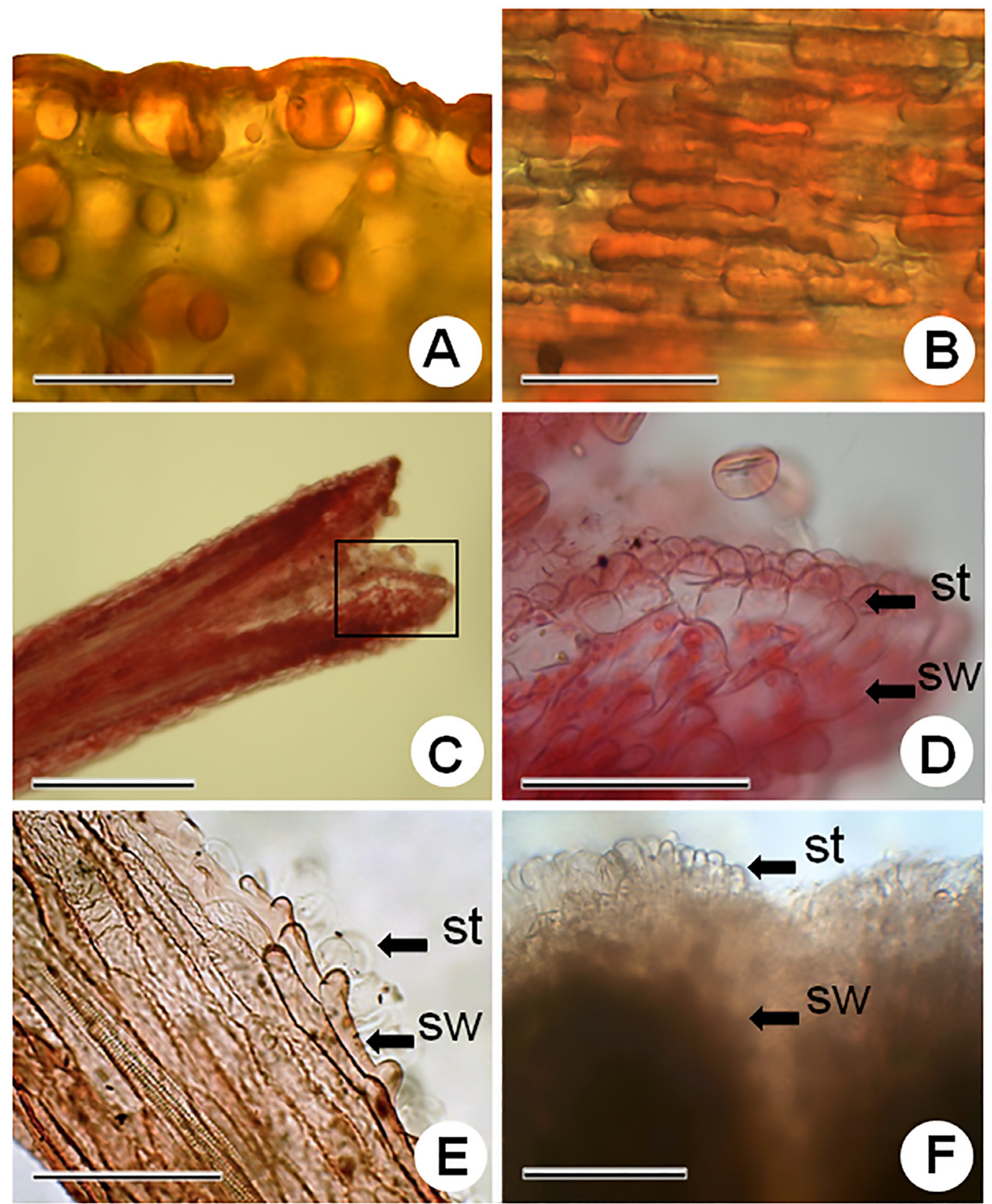

Figure 1. Histochemical results for lipophilic substances. A, B. Fulcaldea stuessyi (Barnadesioideae): A, drops of lipophilic substances contained in the style epidermal cells. B, red drops inside of parenchyma cells. C, D. Doniophyton anomalum (Barnadesioideae): C, lipophilic substances contained in the style parenchymatic cells and sweeping hairs. D, detail of red drops inside of sweeping hairs (sw) and reddish color on cell walls in stigmatic papillae (st), indicated by arrows. E, Chaptalia integerrima (Mutisioideae). F, Cnicothamnus lorentzii (Gochnatioideae). D-F, show lipophilic substances contained in sweeping hairs (sw), and colorless receptive papillae (st). Note the deep red of the sterile outer areas, and the pale red to whitish in the fertile stigmatic area. Scale bars: $100 \mu \mathrm{m}$ in A, B, D-F and $300 \mu \mathrm{m}$ in C. Please see the PDF version for color reference. 

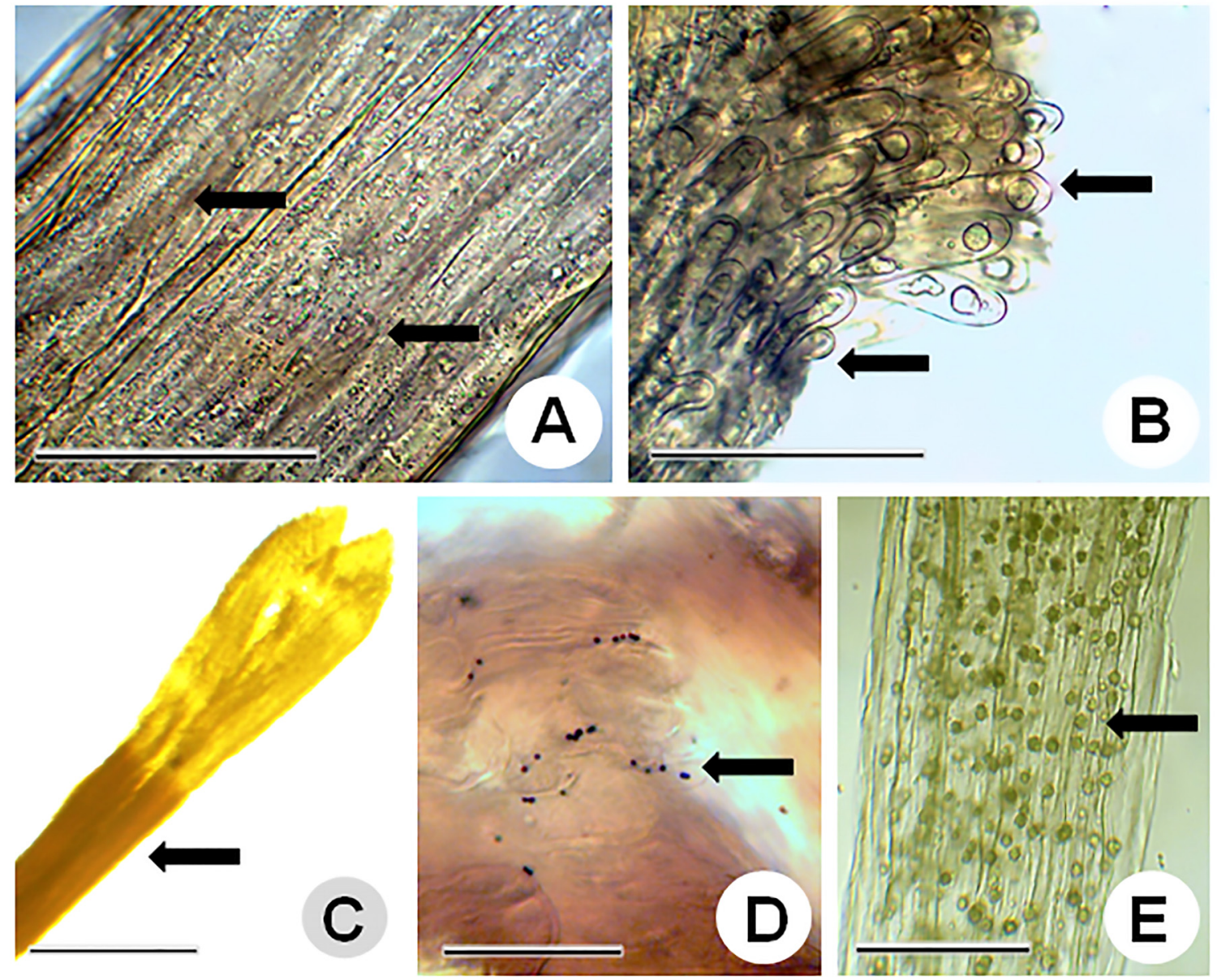

Figure 2. Histochemical results for proteins, reducing sugars, starch, and druses. A. Nassauvia glomerulosa (Multisioideae): light blue-violet color of proteins (granulose aspect) in the cell walls and interior of the style (Biuret test). B. N. aculeata (Multisioideae): detail of the sweeping hairs showing blue-violet color of proteins in the cell walls and in the cell interior (Biuret test). C. Doniophyton anomalum (Barnadesioideae): orange color indicating the presence of reducing sugars in the shaft below the style lobes (Benedict test). D. Hyaloseris cinerea (Stifftioideae): small starch grains dark blue into the style parenchyma cells (IKI reaction). E. Jungia pauciflora (Mutisioideae): druses, crystals of oxalate into the style parenchyma cells (acetic acid reaction). Reactions indicated by arrows. Scale bars: 50 $\mu \mathrm{m}$ in D-E; $100 \mu \mathrm{m}$ in A- B; $1000 \mu \mathrm{m}$ in C. Please see the PDF version for color reference.

being the exception the two species of the genus Fulcaldea, Dasyphyllum ferox and Dasyphyllum tomentosum (Tab. 1). Starch (S): Starch granules were found in the style parenchyma (Fig. 2D) of two species of Barnadesioideae (Dasyphyllum tomentosum and Fulcaldea stuessyi) and six of the sampled species of Mutisioideae, two Stifftioideae, and in Wunderlichia mirabilis (Wunderlichioideae) (Tab. 1). Druses (D): Oxalate salts in the form of druses were observed in the style parenchyma of a few species of the tribes Nassauvieae and Mutisieae of the subfamily Mutisioideae (Fig. 2E).

\section{Discussion}

\section{Histochemistry and taxonomy}

With the phylogenetic tree of Funk et al. (2009) and the distribution of character states, i.e., presence or absence of the analyzed compounds, in the terminal taxa we attempted to reconstruct the character states at the ancestral nodes (Figs. 3-7). A glance at the trees show that members of the subfamily Barnadesioideae are quite uniform in their histochemistry, with the exception of Fulcaldea and some species of Dasyphyllum (Tab. 1). For example, the Peruvian F. laurifolia lacks reducing sugars and lipophilic substances content, whereas the Brazilian F. stuessyi (Funk \& Roque 2011) contains lipophilic substances (as most Barnadesioideae) and starch in the style.

Also notorious are the histochemical similarities in members of Gochnatioideae (lack of starch and druses, and the presence of cytoplasmatic lipophilic substances, proteins, and reducing sugars). Mutisioideae s.s. and Stifftioideae, on the other hand, are quite heterogeneous (Tab. 1). However, the chemical similarities in members of Gochnatioideae are not exclusive of this subfamily since species of Barnadesioideae and Nassauvieae share the same chemical pattern. Because we only sampled one member 


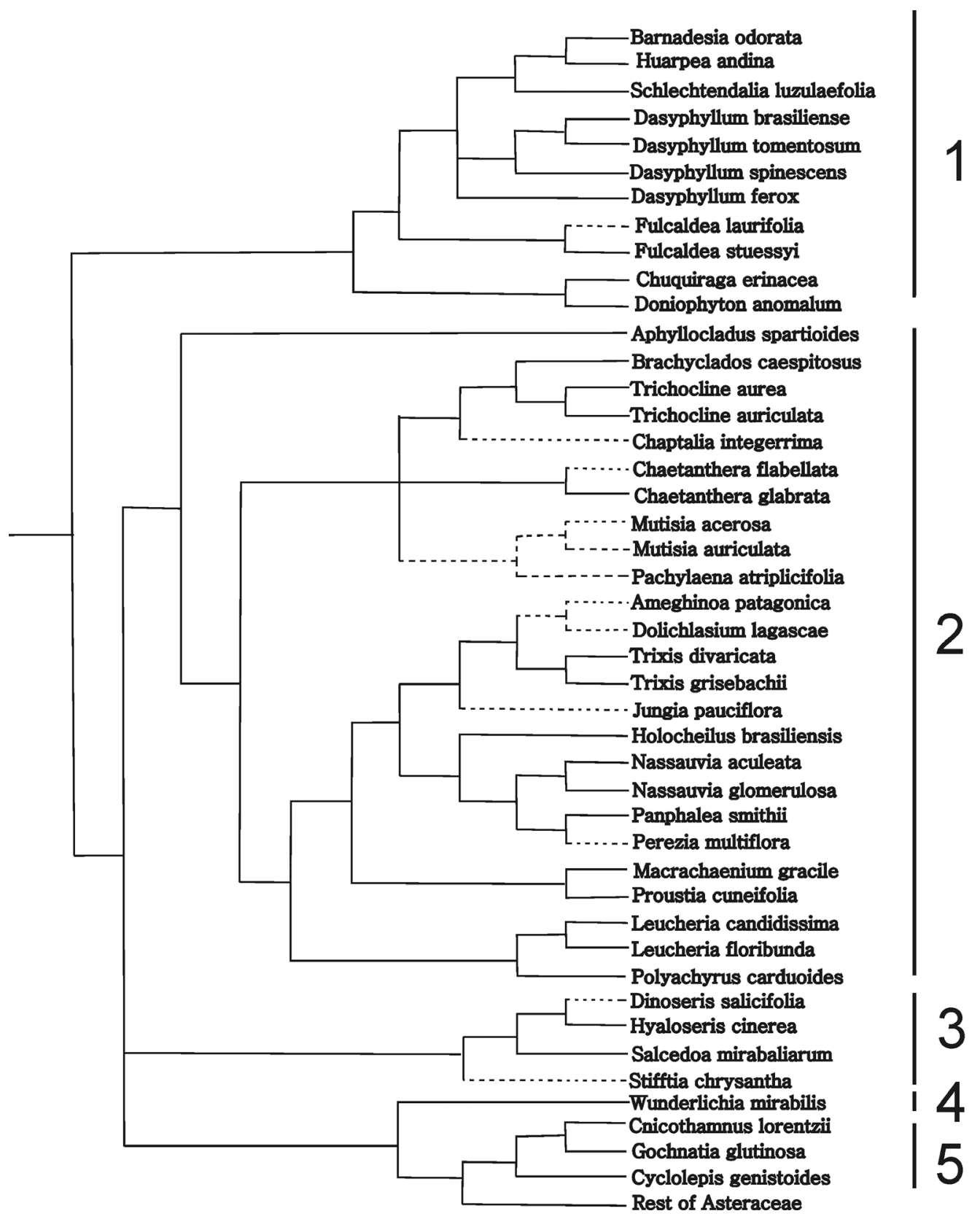

Figure 3. Pruned tree of Funk et al. (2009) including the species phylogenies (see Materials and Methods) with the lipophilic substances contained into the cells optimized onto the tree. Doted lines $=$ absence of lipophilic substances. Continuous lines = presence of lipophilic substances. $1=$ Barnadesioideae; $2=$ Mutisioideae sensu stricto; 3 = Stifftioideae; 4 = Wunderlichioideae; 5 = Gochnatioideae.

of Wunderlichiodeae, no taxonomical conclusions can be established about this subfamily.

Cytoplasmic content of lipophilic compounds predominates in Barnadesioideae and Nassauvieae (Mutisioideae) (Fig. 3), and the same occurs with proteins (Fig. 4) and reducing sugars (Fig. 5). These resemblances would support the parallelism in the evolution of these two groups postulated by Katinas et al. (2007) who established that fossil pollen of Barnadesioideae and Nassauvieae appear together by the first time in the fossil record in the Early Miocene

\section{(23-20 Ma) of Patagonia, Argentina.}

The sporadic presence of druses is only present in Mutisioideae (Ameghinoa patagonica, Chaetanthera glabrata, Jungia pauciflora, Nassauvia aculeata, Trichocline aurea, and Trixis grisebachii) (Fig. 7). Further studies are needed to establish if the presence of crystals is associated to the environmental conditions (e.g., quantity of calcium, magnesium ions and $\mathrm{pH}$ in the soil) as postulated by some authors (Franceschi \& Horner 1980; Apóstolo 1999; 2005). On the other hand, calcium oxalate crystals were surveyed in the 


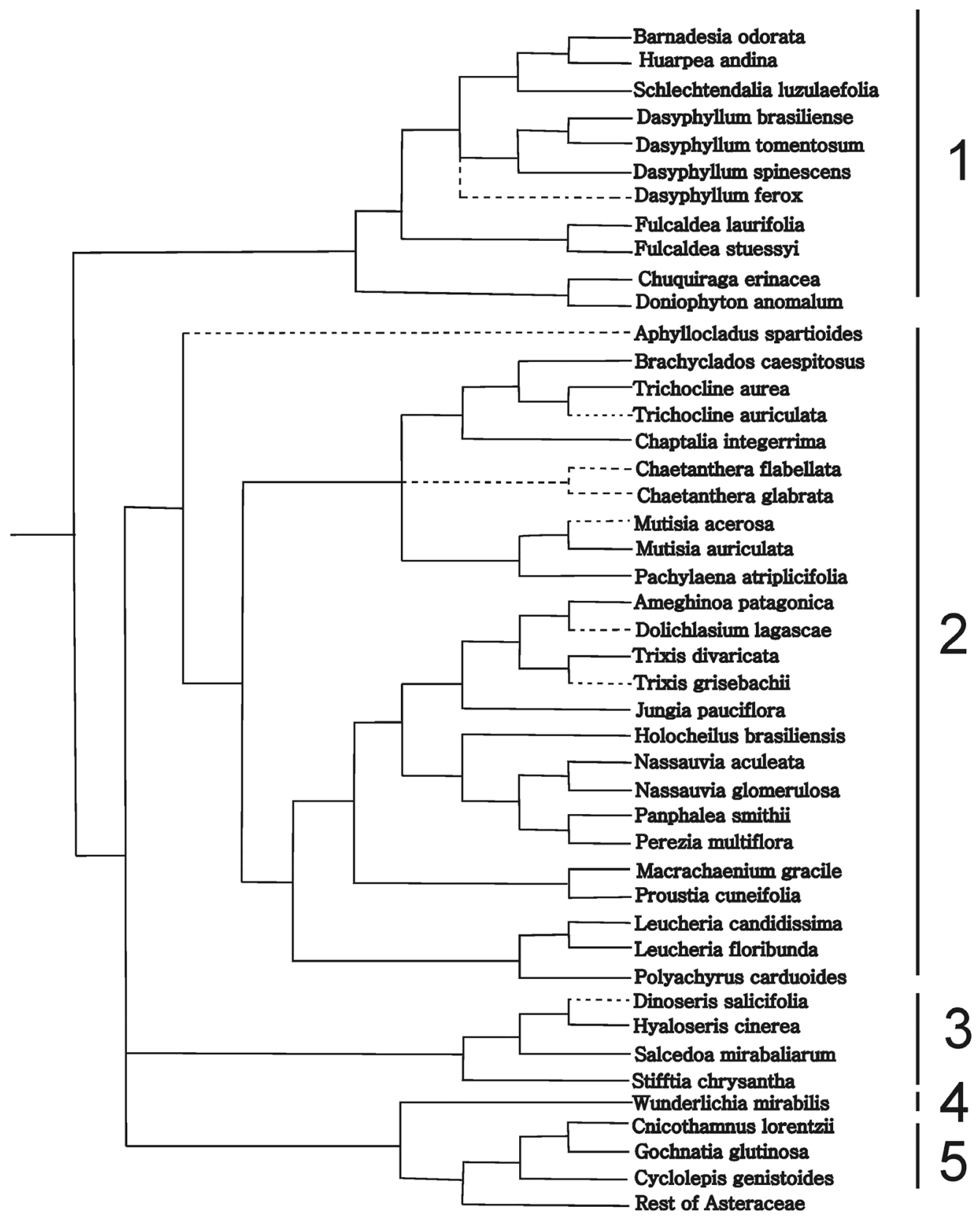

Figure 4. Pruned tree of Funk et al. (2009) including the species phylogenies (see Materials and Methods) with the proteins optimized onto the tree. Doted lines $=$ absence of proteins. Continuous lines $=$ presence of proteins. $1=$ Barnadesioideae; $2=$ Mutisioideae sensu stricto; $3=$ Stifftioideae; $4=$ Wunderlichioideae; $5=$ Gochnatioideae.

ovaries of species of Centaurea (Carduoideae, Asteraceae) and a correlation was found between the shape of the crystals and the pollen types in the genus (Dormer 1962).

Despite the fact of some coherence in the presence or absence of chemical components, we cannot conclude with certainty that there is a strong correlation between the histochemistry and the current classification of basal groups of Asteraceae as we expected initially. Of course, this statement can be tested with more sampling.

\section{Histochemistry and morphology}

Heslop-Harrison \& Shivanna (1977) described the stigmatic surface of styles of Asteraceae as dry, which lack a copious surface secretion and are covered by a continuous cuticle overlaid by a thin proteinaceous pellicle. In spite of the dry nature of cuticularized stigmas, it was postulated that a lipid surface is an essential factor for pollen tubes to penetrate the stigma by controlling the flow of water to pollen (Wolters-Arts et al. 1998). The histochemical analyses 


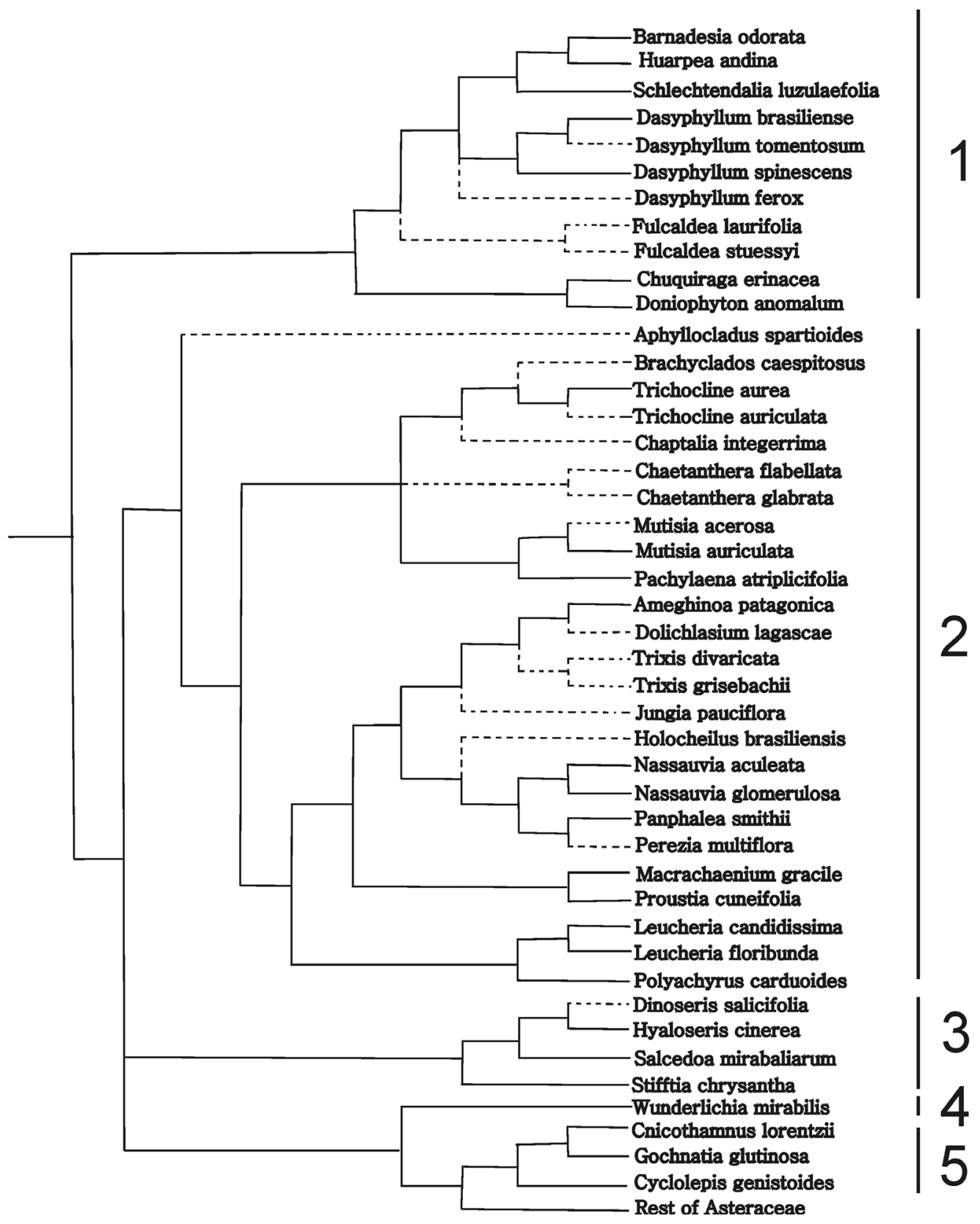

Figure 5. Pruned tree of Funk et al. (2009) including the species phylogenies (see Materials and Methods) with the reducing sugars optimized onto the tree. Doted lines $=$ absence of reducing sugars. Continuous lines = presence of reducing sugars. $1=$ Barnadesioideae; $2=$ Mutisioideae sensu stricto; $3=$ Stifftioideae; $4=$ Wunderlichioideae; 5 = Gochnatioideae.

performed here, corroborate these findings showing impregnation of lipophilic compounds in the cuticle and cell walls of stigmatic papillae but also in all the epidermal style cells. Similar results were obtained in genera of other subfamilies of Asteraceae, Lessingianthus and Lucilia (Teixeira et al. 2011), where lipids stained with Sudan III technique were reported in stigmatic papillary cells. We extend these findings by showing that the sweeping hairs, together with the other style cells, with the notable exception of the stigmatic cells, have lipophilic substances in the interior of the cells. The cell cytoplasms of the stigmatic areas have not lipophilic substances and, if present, they are in very low quantities allowing a clear chromatic differentiation with the non-fertile areas. The fact that the lipophilic substances are differentially disposed in the inner (fertile) and in the outer (sterile) side of the branches have important implications for future studies where sterile and fertile parts in the styles must be recognized.

Proteins are present in the style cells of most of the species analyzed, in fertile and sterile areas. Other stud- 


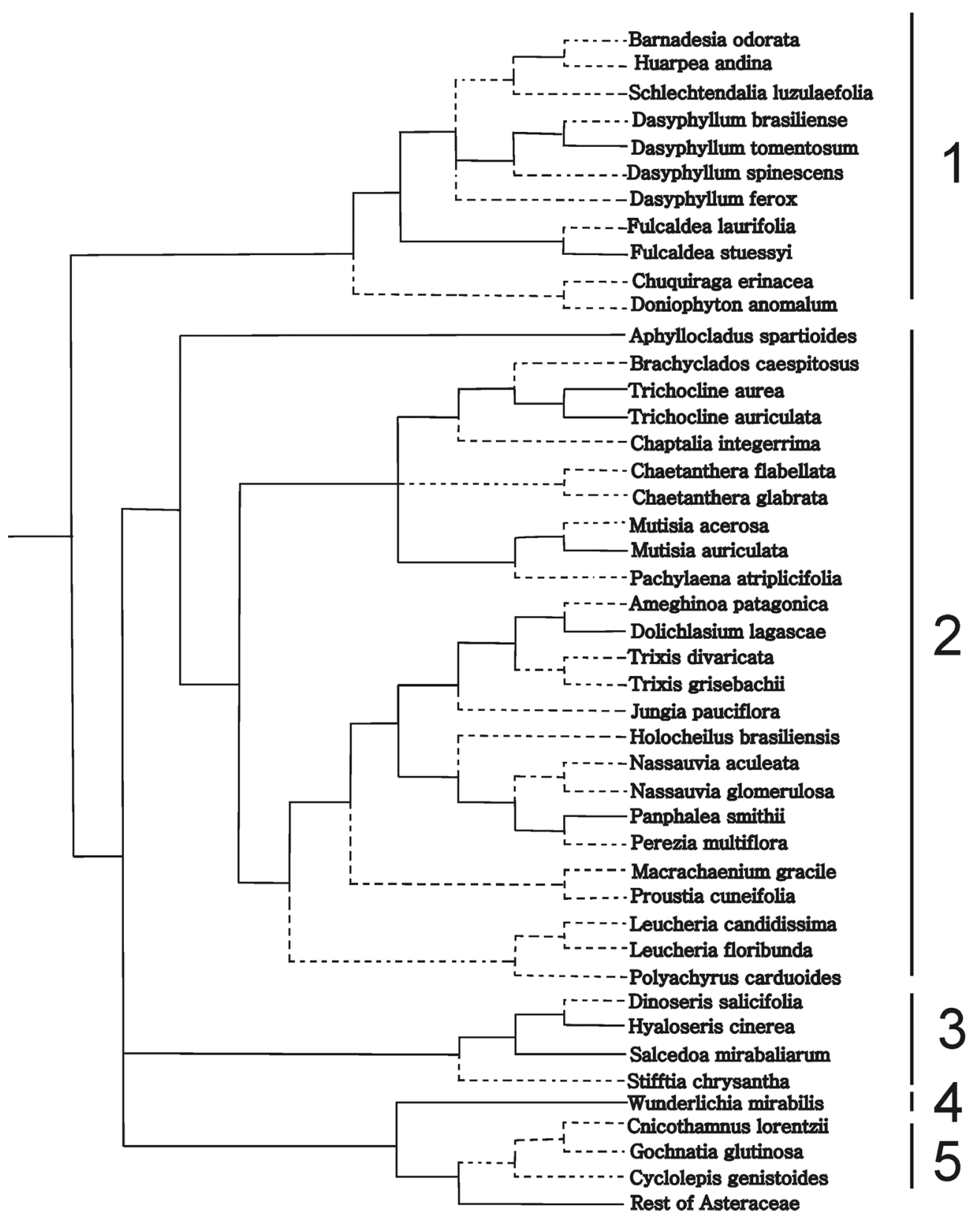

Figure 6. Pruned tree of Funk et al. (2009) including the species phylogenies (see Materials and Methods) with the starch optimized onto the tree. Doted lines $=$ absence of starch. Continuous lines $=$ presence of starch. $1=$ Barnadesioideae; $2=$ Mutisioideae sensu stricto; $3=$ Stifftioideae; $4=$ Wunderlichioideae; $5=$ Gochnatioideae

ies, on the other hand, reveal more protein content in the fertile areas of the styles. This is the case of Cynara (Asteraceae) (Ramalho-Santos et al. 1997) of the subfamily Carduoideae. These authors found that the expression of the enzyme cardosin A is highly restricted to the pistils, and that it accumulates mainly in protein storage vacuoles of the stigmatic papillae. The authors attributed a possible physiological role of this enzyme in defense mechanisms, pollen-pistil interaction, as well as in flower senescence. Our results, based on Biuret test did not show such speci- ficity for fertile areas. It is posible that additional tests (e.g. Coomassie blue, Xylidine Ponceau, Aniline blue black or Naphthol blue black) yield different results to verify the absence/presence of proteins.

Regarding the carbohydrates, most species showed reducing sugars in their style cells but only some species had starch grains. Studies performed in ovaries and styles of avocado and other crop species (Alcaraz et al. 2013) yielded that at anthesis the cells of the style were rich in starch, and starch content decreased in the days following anthesis suggesting 


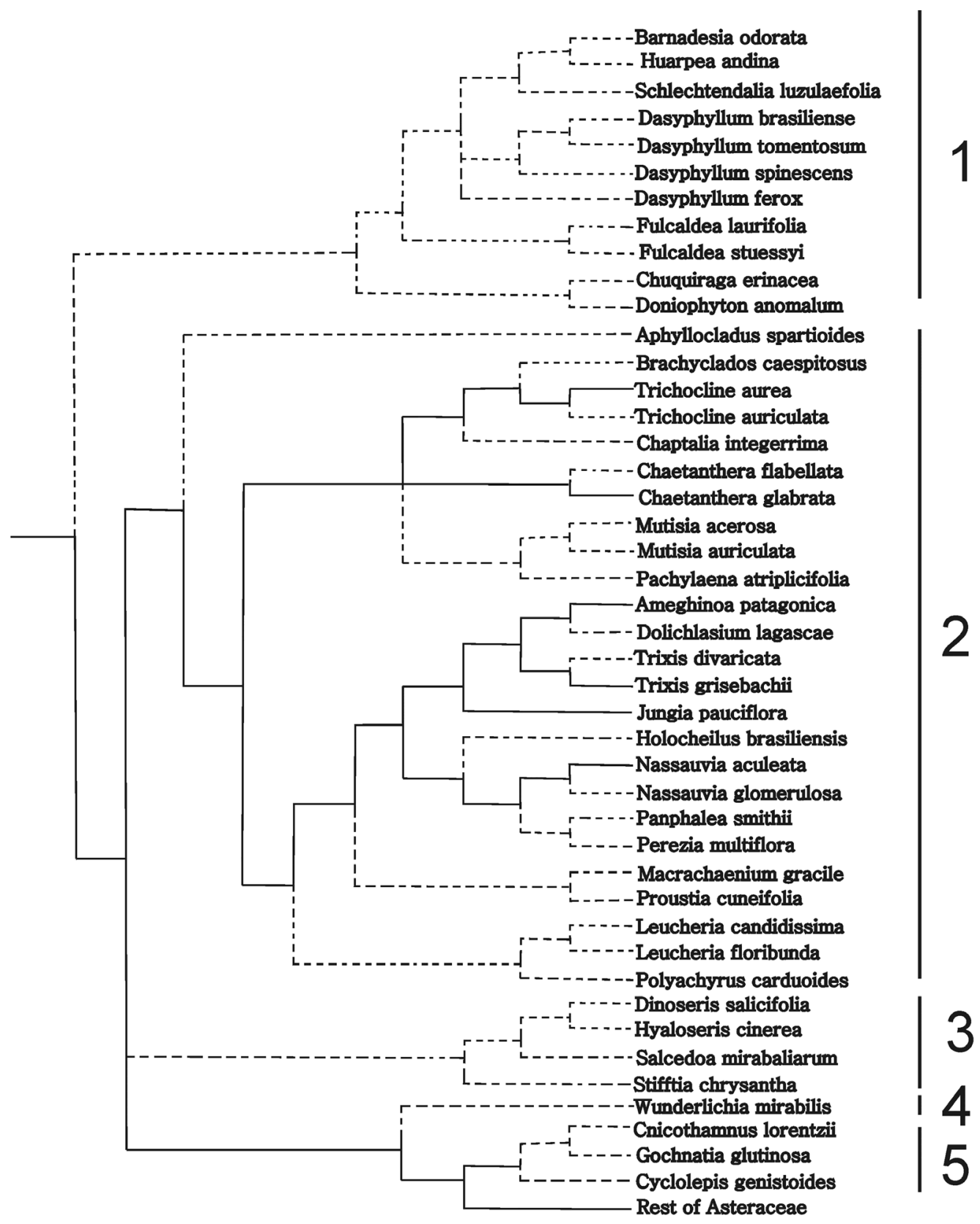

Figure 7. Pruned tree of Funk et al. (2009) including the species phylogenies (see Materials and Methods) with the druses optimized onto the tree. Doted lines $=$ absence of druses. Continuous lines = presence of druses. 1 = Barnadesioideae; 2 = Mutisioideae sensu stricto; $3=$ Stifftioideae; $4=$ Wunderlichioideae; $5=$ Gochnatioideae.

a role in nutritive reserves in flower fertilization. Also, the starch content in the pistil at anthesis could be a good indicator of flower quality because it was present in all flowers that developed into fruits. Studies in Asteraceae should be performed to test if the amount of starch in pistils has some significate relevance in fertilization and fruit production.

In conclusion, this is the first study performed in Asteraceae that analyzes a set of chemical substances in the styles to search for possible taxonomic implications. Histochemical methods have been found to be of relatively value, although it might be complementary to other studies. The subfamilies
Barnadesioideae and Gochnatioideae (Tab. 1, Figs. 3-7) are the most homogeneous regarding chemical compounds in the styles. An important outcome of this contribution is the use of lipophilic substances as indicators to differentiate the fertile and the sterile areas of styles (Fig. 1D-F), for example in secondary pollen presentation studies. Because styles are a key to reproduction, the integration of histochemical and morphological studies could be of importance in families such as Asteraceae to understand its evolutionary history. Future research in species of other tribes is required to provide a sound basis for our findings. 


\section{Acknowledgements}

Thanks to L. M. I. López for critical reading and suggestions on the manuscript, and J. V. Crisci for critical reading and help with the software. We are also grateful to curators of herbaria, specially to Nadia Roque, who allowed us to examine material. Our acknowledge to Agencia Nacional de Promoción Científica y Tecnológica (SECYT), Consejo Nacional de Investigaciones Científicas y Técnicas (CONICET), and Universidad Nacional de La Plata (UNLP).

\section{References}

Alcaraz ML, Hormaza JI, Rodrigo J. 2013. Pistil starch reserves at anthesis with final flower fate in avocado (Persea americana). PLoS ONE 8: e78467. doi: 10.1371/journal.pone.0078467.

Apóstolo NM. 1999. Anatomía ecológica de la comunidad costera del río Salado, (noroeste de la provincia de Buenos Aires partidos de Alberti, Bragado y Junín). PhD Thesis, Universidad de Buenos Aires, Argentina.

Apóstolo NM. 2005. Caracteres anatómicos de la vegetación costera del Río Salado (noroeste de la provincia de Buenos Aires, Argentina). Boletín de la Sociedad Argentina de Botánica 40: 215-227.

Bentham G, Hooker JD. 1873. Genera plantarum ad exemplaria imprimis in herbariis kewensibus servata definite. Vol. 2. London, Lovell, Reeve and Co.

Bessa J, Cruz KC, Vieira MF. 2010. Location of the stigmatic areas in Mutisia speciosa Aiton ex Hook.: A new floral feature in Asteraceae. Sexual Plant Reproduction 23: 207-209.

Bohm BA, Stuessy TF. 2001. Flavonoids of the sunflower family (Asteraceae). Wien - New York, Springer.

Bremer K. 1994. Asteraceae: Cladistics and classification. Portland Oregon, Timber Press.

Cabrera AL. 1961. Compuestas argentinas. Clave para la determinación de géneros. Revista Museo Argentino de Ciencias Naturales "Bernardino Rivadavia”. Instituto Nacional de Investigación de las Ciencias Naturales, Botánica 2: 291- 362.

Cabrera AL. 1977. Mutisieae- Systematic review. In: Heywood VH, Harborne JB, Turner BL. (eds.) The biology and chemistry of the Compositae, v. 2. London, Academic Press. p. 1039-1066.

Crisci JV. 1974. A numerical taxonomic study of the subtribe Nassauviinae (Compositae, Mutisieae). Journal of the Arnold Arboretum 55: 568-610.

Dormer KJ. 1962. The taxonomic significance of crystal forms in Centaurea. New Phytologist 61: 32-35.

Edeoga HO, Okwu DE, Mbaebie BO. 2005. Phytochemical constituents of some Nigerian medicinal plants. African Journal of Biotechnology 4: 685-688.

Franceschi V, Horner H. 1980. Calcium oxalate crystals in plants. Botanical Review 46: 361-427.

Funk VA, Roque N. 2011. The monotypic Andean genus Fulcaldea (Compositae, Barnadesioideae) gains a new species from northeastern Brazil. Taxon 60: 1095-1103.

Funk VA, Susanna A, Stuessy TF, Robinson H. 2009. Classification of Compositae. In: Funk VA, Susanna A, Stuessy TF, Bayer R. (eds.) Systematics, Evolution and Biogeography of the Compositae. Vienna, IAPT. p. 171-189.

Funk VA, Sancho G, Roque N, et al. 2014. A phylogeny of Gochnatieae: Undestanding critically placed tribe in the Compositae. Taxon 63: 859-882.
Gotelli MM, Galati BG, Medán D. 2010. Structure of the stigma and the style in sunflower (Helianthus annuus L.). Biocell 32: 133-138.

Heslop-Harrison Y, Shivanna KR. 1977. The receptive surface of the angiosperm stigma. Annals of Botany 41: 1233-1258.

Hiscock SJ. 2000. Genetic control of self-incompatibility in Senecio squalidus L. (Asteraceae): a successful colonizing species. Heredity 85: 10-19.

Johansen DA. 1940. Plant microtechnique. New York, McGraw-Hill Book Company.

Katinas L. 1994. Un Nuevo género de Nassauviinae (Asteraceae, Mutisieae) y sus relaciones cladísticas con los géneros afines de la subtribu. Boletin de la Sociedad Argentina de Botánica 30: 59-70.

Katinas L, Crisci JV, Tellería MC, Barreda V, Palazzesi L. 2007. Early history of Asteraceae in Patagonia: evidence from fossil pollen grains. New Zealand Journal of Botany 45: 605-610.

Katinas L, Pruski J, Sancho G, Tellería MC. 2008a. The subfamily Mutisioideae (Asteraceae). Botanical Review 74: 469-716.

Katinas L, Crisci JV, Schmidt Jabaily R, et al. 2008b. Evolution of secondary heads in Nassauviinae (Asteraceae, Mutisieae). American Journal of Botany 95: 229-240.

Knox RB. 1973. Pollen-wall proteins: pollen-stigma interactions in ragweed and Cosmos (Compositae). Journal of Cell Science 12: 421-443.

Korwar PG, Beknal AK, Patil BS, et al. 2010. A study on phytochemical investigation of Drynaria quercifolia Linn rhizome. International Journal of Pharmaceutical Science and Research 1: 148-158.

Nascimento-Silva O, Souza Leite D, Aparecida-Bernardes L, Antunes de Paiva JG. 2011. Morphology, anatomy and histochemistry of the leaves of Myracrodruon urundeuva Allemão (Anacardiaceae). Boletín Latinoamericano y del Caribe de Plantas Medicinales y Aromáticas 10: 56-66.

Panero JL, Funk VA. 2008. The value of sampling anomalous taxa in phylogenetic studies: major clades of the Asteraceae revealed. Molecular Phylogenetics and Evolution 47: 757-782.

Pansarin ER, Aguiar JMRBV, Pansarin LM. 2014. Floral biology and histochemical analysis of Vanilla edwallii Hoehne (Orchidaceae: Vanilloideae): an orchid pollinated by Epicharis (Apidae: Centridini). Plant Species Biology 29: 242-252.

Ramalho-Santos M, Pisarra J, Veríssimo P, et al. 1997. Cardosin A, an abundant aspartic proteinase, accumulates in protein storage vacuoles in the stigmatic papillae of Cynara carduculus L. Planta 203: 204-212.

Ruzin SE. 1999. Plant microtechnique and microscopy. Oxford, Oxford University Press.

Schorr K, Costa FB. 2003. A proposal for chemical characterization and quality evaluation of botanical raw materials using glandular trichome microsampling of yacón (Polymnia sonchifolia, Asteraceae), an Andean medicinal plant. Revista Brasileira de Farmacognosia, Brazilian Journal of Pharmacognosy 13: 1-3.

Small J. 1919. The origin and development of the Compositae. New Phytologist 11: 1-333.

Stuessy TF, Urtubey E, Gruenstaeudl M. 2009. Barnadesieae (Barnadesioideae). In: Funk VA, Susanna A, Stuessy TF, Bayer R. (eds.) Systematics, Evolution and Biogeography of the Compositae. Vienna, IAPT. p. 215-228.

Swofford DL. 2002. PAUP*. Phylogenetic Analysis Using Parsimony ( ${ }^{*}$ and other methods). Version 4. Sunderland, Massachusetts, Sinauer Associates.

Teixeira SP, Capucho LC, Machado SR. 2011. Two novel reports of semidry stigmatic surface in Asteraceae. Flora 206: 328-333.

Wolters-Arts M, Lush WM, Mariani C. 1998. Lipids are required for directional pollen-tube growth. Nature 392: 818-821.

Yasue T. 1969. Histochemical identification of calcium oxalate. Acta Histochemica et Cytochemica 2: 83-95.

Zarlavsky GE. 2014. Histologia vegetal. Técnicas simples y complejas. Sociedad Argentina de Botánica. Buenos Aires, Argentina. 